\title{
Structural analysis of the Pimelodus maculatus (Lacépède, 1803) embryogenesis (Siluriformes: Pimelodidae)
}

\author{
Hellen Buzollo ${ }^{1}$, Rosicleire Veríssimo-Silveira² ${ }^{2}$ Isângela R. Oliveira-Almeida², \\ Juliana S. Alexandre ${ }^{2}$, Hélio T. Okuda ${ }^{3}$ and Alexandre Ninhaus-Silveira ${ }^{2}$
}

The fish embryonic development comprises the events between the egg fertilization up to larvae hatching, being useful for the identification of viable eggs in productivity and survival studies as well as in raising experiments of several species. The goal of the present study was to characterize the embryonic development of Pimelodus maculatus (Siluriformes; Pimelodidae). The embryogenesis was typical of teleosteans, but with differences in relation to other species such as duration of development, type of blastocoel, moment of somite segmentation among others. Six stages of embryonic development were defined: zygote, cleavage, blastula, gastrula, organogenesis (divided in phases: early segmentation and late segmentation) and hatching with a period of incubation equal to 13 hours at $29^{\circ} \mathrm{C}$ and 17 hours at $25^{\circ} \mathrm{C}$. The extruded oocytes presented a mean diameter of $812 \mu \mathrm{m}$ before and $1066 \mu \mathrm{m}$ after hydration. When fertilized, they presented a yellowish coloration and a gelatinous layer surrounding the chorion. The cleavage pattern is described as: $2 ; 4 ; 8(4 \times 2) ; 16(4 \times 4) ; 32(4 \times 8)$ and $64(2 \times 4 \times 8)$ blastomeres up to morula phase $(+64$ cells). It was also possible to observe at this phase, the beginning of the formation of the yolk syncyctial layer (YSL). Afterwards, the blastula and gastrula stages followed. The end of gastrula was characterized by the formation of the yolk plug. Subsequently, the differentiation between cephalic and caudal regions began, along with the embryo elongation, structuring of optic, Kupffer's and otic vesicles besides a previously unidentified structure in the yolk syncyctial layer. The end of this stage is typified by the tail detachment. The late segmentation phase was distinguished by a free tail, presence of more than 30 somites, optic and otic vesicles, development of posterior intestine, pigmentation of cephalic and caudal regions of yolk sac and embryo growth. The recently-hatched larvae presented a primordial digestive tract, quite evident and pigmented eyes, closed mouth, encephalic vesicles and a mean length of $3410 \mu \mathrm{m}$.

O desenvolvimento embrionário de peixes compreende eventos que ocorrem desde o ovo fertilizado à eclosão das larvas, podendo auxiliar na identificação dos ovos viáveis em estudos de produtividade e sobrevivência, como também nas pesquisas de cultivo desses animais. O objetivo do presente estudo foi caracterizar o desenvolvimento embrionário do Pimelodus maculatus (Siluriformes; Pimelodidae). A embriogênese foi característica de teleósteos, apresentando variações que difere de outras espécies como, tempo de desenvolvimento, tipo da blastocele, momento de segmentação dos somitos, entre outros. Seis estágios de desenvolvimento embrionário foram definidos: zigoto, clivagem, blástula, gástrula, organogênese (dividido em fases: segmentação inicial e segmentação final) e eclosão com período de incubação de 13 horas à $29^{\circ} \mathrm{C}$ e de 17 horas à $25^{\circ} \mathrm{C}$. Os ovócitos extrusados apresentaram diâmetro médio de $812 \mu \mathrm{m}$ antes da hidratação e após $1066 \mu \mathrm{m}$. Após a fertilização, apresentaram coloração amarelada e uma camada gelatinosa envolvendo o córion. O padrão de clivagens foi descrito como segue: 2; 4; 8 (4x2); $16(4 \times 4)$; 32 (4x8) e 64 (2x4x8) blastômeros até a fase de mórula (+64 células). Também foi possível observar nesta fase, o início da formação da camada sincicial do vitelo (CSV). Em seguida foram observados os estágios de blástula e gástrula. O final da gástrula caracterizou-se pela formação do tampão vitelino. A seguir, iniciou-se a diferenciação das regiões cefálica e caudal, o alongamento

\footnotetext{
${ }^{1}$ Universidade Estadual Paulista, Faculdade de Ciências Agrárias e Veterinárias, FCAV/UNESP. Via de Acesso Professor Paulo Donato Castellani, s/n, Rural, 14884-900 Jaboticabal, São Paulo, Brazil. hellen_buzollo@yahoo.com.br

${ }^{2}$ Laboratório de Ictiologia Neotropical, L.I.NEO, Dep. Biologia e Zootecnia, FEIS/UNESP, Avenida Brasil, 56- Centro, 15085-000 Ilha Solteira, São Paulo, Brazil.rosiverissimo@yahoo.com.br, isangela@ibb.unesp.br,jusversut@hotmail.com and ninhaus@bio.feis.unesp.br (corresponding author)

${ }^{3}$ Dep. Biologia e Zootecnia, FEIS/UNESP, Avenida Brasil, 56, Centro, 15085-000 Ilha Solteira, São Paulo, Brazil. okuda@bio.feis.unesp.br
} 
do embrião, estruturação das vesículas ópticas, de Kufper, óticas e de uma estrutura não identificada na literatura localizada na camada sincicial do vitelo. O final deste estágio é demarcado pelo desprendimento da cauda. A fase de segmentação final caracterizou-se pela cauda livre, presença de mais de 30 somitos, vesícula óptica e ótica, desenvolvimento do intestino posterior, pigmentação nas regiões cefálica e caudal do saco vitelino e crescimento do embrião. As larvas recém-eclodidas apresentaram esboço do trato digestório, olhos bem evidentes e pigmentados, boca fechada, presença das vesículas encefálicas e com comprimento médio de $3410 \mu \mathrm{m}$.

Key words: Embryonic development, Induced spawning, Morphology, Yolk syncyctial layer.

\section{Introduction}

Brazil presents a remarkable hydrographic and climatic potential as well as the richest fish fauna of the world, therefore being one of the most promising countries for aquaculture expansion. Although aquaculture technologies for neotropical fish species in Brazil are in development, it is still necessary to increase the information about biological features of species with potential to fishculture (Ninhaus-Silveira et al., 2006; Castagnolli, 1992).

The species Pimelodus maculatus belongs to the family Pimelodidae, order Siluriformes, It is an omnivorous and widespread catfish popularly known as "mandi, mandi-amarelo or mandi-pintado". This species is widely distributed in Brazil (Nomura, 1978), being found in Paraná, Plata and São Francisco river basins (Godoy, 1987; Reis et al., 2003), Colombia, Maranhão, Jequitinhonha, Doce e Paraíba rivers (Fowler, 1951 apud Nakatani et al., 2001). According to Castagnolli (1979) and Weingartner \& Zaniboni Filho (2004), the Pimelodus maculatus is a species with potential for aquaculture and has interesting features, such as good quality meat and the absence of intramuscular bones, as well as adapting easily to artificial feeding, which represents a positive aspect to consider the feasibility of intensive breeding. Accordingly, studies suggest that improvements in technologies for building are important.

The early development and the embryologic description are important features to be studied in fish species since the knowledge of their biological features is a fundamental tool for both fishculture and fishery biology (Matkovic et al., 1985). In addition, the embryological approach can contribute to studies regarding evolutionary relationships, inheritance pattern, mechanisms of development and the role of environmental influences over structural features of the organisms (Lagler, 1959). Morrison et al. (2001) suggest that the variations in the rate of embryogenesis and embryo development (asynchrony and malformations) are related to the breeders' age and the temperature of incubation.

According to Nakatani et al. (2001), in spite of several reports about embryonic development and larvae culture, there are few studies addressing the complete early development of native fish species (e.g., Ribeiro et al., 1995; Andrade-Talmelli et al., 2001; Ganeco, 2003; Pereira et al., 2006; Ninhaus-Silveira et al., 2006 and Faustino et al., 2007). Data about the embryonic development of Pimelodus maculatus are restricted to the studies by Luz et al. (2001) and Sato (1999).
Therefore, the goal of the present study was to characterize, under light microscopy, the several morphological events during the embryonic development stage of the Pimelodus maculatus.

\section{Material and Methods}

The experiment was carried out with adult specimens of Pimelodus maculatus from CEPTA - Centro de Pesquisa e Gestão de Recursos Pesqueiros Continentais - ICMBIO (Instituto Chico Mendes de Conservação da Biodiversidade), Pirassununga, São Paulo, Brazil. To obtain the embryos, two collections were performed in November 2007, during the reproductive period of this species that ranges from October to March (Vazzoler, 1996).

The spawning induction of breeders followed the procedure described by Woynarovich and Hórvath (1983), using a crude common carp (Cyprinus carpio) pituitary extract; three females with approximately $0.5 \mathrm{~kg}$ in weight each received two applications with a dosage of $0.5 \mathrm{mg}$ and $5 \mathrm{mg} /$ $\mathrm{kg}$, respectively, in a 10 -hour interval. Two adult male specimens weighing $0.5 \mathrm{~kg}$, were induced to spawn with an application of $1 \mathrm{mg} / \mathrm{kg}$ simultaneously with the second application of females. After about six hours from the last inductive dosage, the eggs were extruded and the semen was collected. The "dry" method was used for fertilization, where the eggs are mixed to semen without contact with water. Afterwards, water was added to activate the spermatozoa and hydrate the eggs. After washing to remove the excess of semen, the eggs were divided into two sets for incubation at different temperatures $\left(25^{\circ} \mathrm{C}\right.$ and $\left.29^{\circ} \mathrm{C}\right)$. The incubators were connected to a closed heated water system coupled with a thermostat. To evaluate possible morphotemporal alterations in embryos of Pimelodus maculatus, samples of 200 embryos were collected at random at different development stages, regarding the moment of fecundation as time zero. In the eggs incubated at $29^{\circ} \mathrm{C}$, the collections were performed each 15 minutes up to the first two hours of embryogenesis, and then each hour up to hatching. The samples of eggs incubated at $25^{\circ} \mathrm{C}$ were obtained each five minutes up to the first hour, each 10 minutes up to the second development hour and then each hour up to larvae hatching. The embryo samples were fixed in modified Karnovsky's fixative solution (4\% paraformaldehyde and $2 \%$ glutaraldehyde, in $0.1 \mathrm{M}$ phosphate buffer, $\mathrm{pH}$ 7.2). After 24 hours, the samples were washed in 
$0.1 \mathrm{M}$ sodium phosphate buffer, $\mathrm{pH} 7.2$ and kept in refrigerated $70 \%$ alcohol $\left(10^{\circ} \mathrm{C}\right)$.

\section{Stereoscopic analysis}

The pre-fixed material was soon after processed, analyzed and photomicrographed in the Laboratório de Ictiologia Neotropical - L.I.NEO, Departamento de Biologia e Zootecnia - FEIS/UNESP, Ilha Solteira, São Paulo, Brazil.

For analysis, 50 embryos of each sample were selected and the chorion was removed using a watchmaker tweezer and a needle. The embryos were stained with Harris hematoxylin and eosin (HE), analyzed and photographed under a trinocular stereo microscope Coleman equipped with a Motic 2000 digital camera (Motic Instruments Inc.).

\section{Light microscopy analysis}

Twenty representative pre-fixed specimens from each development stage were embedded individually and oriented in glycol metacrylate plastic resin for microtomy. Serial transversal and sagittal histological cuts of 3 to $5 \mu \mathrm{m}$ were obtained and stained with Harris hematoxylin and eosin (HE) and toluidine blue, analyzed and photographed in a microscope Carl Zeiss Jena equipped with a Moticam 2000 digital camera (Motic Instruments Inc.).

\section{Results}

\section{Embryogenesis}

The embryonic development of Pimelodus maculatus from fertilization up to larvae hatching comprised a period of 13 hours at $29^{\circ} \mathrm{C}$ and 17 hours at $25^{\circ} \mathrm{C}$. The following stages were established: zygote, cleavage, blastula, gastrula, organogenesis (divided in phases: early segmentation e late segmentation) and hatching (Tables 1 and 2; Figs.1-3). Heterogeneity was observed during the embryo development, i.e., embryos at different embryonic stages were observed at the same moment. In Pimelodus maculatus, the temperature at $25{ }^{\circ} \mathrm{C}$ yielded both a higher asynchrony in the embryonic development and a wider variation in the blastomere division and the embryo formation was more homogeneous than incubation at $29^{\circ} \mathrm{C}$.

\section{Zygote stage. $0-0.23 \mathrm{~h}\left(29^{\circ} \mathrm{C}\right) ; 0-0.42 \mathrm{~h}\left(25^{\circ} \mathrm{C}\right)$}

Right after spawning, the oocytes were spherical, transparent and yellowish, being classified as telolecithal, once they present a large amount of yolk restricted to the vegetative pole. After fertilization, the egg became hydrated with an increased perivitelline space $(31.3 \%)$, pronuclei fusion and cytoplasm reorganization with definition of both animal and vegetal poles (Figs. 4a-c). The animal pole is composed of active cytoplasm and a nucleus, being identifiable in vivo and in light microscope analyses because it is more transparent (Fig. 4c). On the other hand, the vegetal pole was denser in vivo with a faint coloration in the total preparations. The eggs presented a gelatinous surrounding layer (Figs. 4a-b) from spawning, when the oocytes were still dehydrated, up to the end of gastrula. During the entire embryonic development, fat drops in the yolk vesicle were not observed.

The eggs of Pimelodus maculatus were measured in vivo and presented nearly $812 \mu \mathrm{m}$ and $1066 \mu \mathrm{m}$ in diameter prior and after hydration, respectively.

Table 1. Embryonic development of Pimelodus maculatus, at $29^{\circ} \mathrm{C}$.

\begin{tabular}{|c|c|c|}
\hline Time (hours) & Stage & Observations \\
\hline $0-0.23$ & Zygote & Animal pole without cleavage \\
\hline 0.40 & Cleavage & $100 \%$ with 2 cells \\
\hline \multirow[t]{2}{*}{0.65} & Cleavage & $7 \%$ with 4 cells \\
\hline & & $93 \%$ with 8 cells \\
\hline \multirow[t]{2}{*}{1.00} & Cleavage & $73 \%$ with 16 cells \\
\hline & & $27 \%$ with 32 cells \\
\hline \multirow[t]{2}{*}{1.25} & Cleavage & $6 \%$ with 16 cells \\
\hline & & $94 \%$ with 32 cells \\
\hline 1.50 & Cleavage & $100 \%$ with 64 cells \\
\hline \multirow[t]{2}{*}{1.75} & Cleavage & $100 \%$ morula \\
\hline & Blastula & \\
\hline \multirow[t]{2}{*}{2.00} & Cleavage & $100 \%$ morula \\
\hline & Blastula & \\
\hline 2.25 & Gastrula & $100 \%$ with $25 \%$ of epiboly \\
\hline 3.00 & Gastrula & $100 \%$ with $50 \%$ of epiboly \\
\hline 4.00 & Gastrula & $100 \%$ with $75 \%$ of epiboly \\
\hline 5.00 & Gastrula & $100 \%$ with $90 \%$ of epiboly \\
\hline 6.00 & Organogenesis & Early segmentation phase $-100 \%$ neurula \\
\hline 7.00 & & $\begin{array}{l}\text { Early segmentation phase- } 11 \text { somites, optic vesicle, otic vesicle, Kupffer's vesicle, pigmentation of embryo } \\
\text { body and attached tail. }\end{array}$ \\
\hline 8.00 & & $\begin{array}{l}\text { Early segmentation phase - } 14 \text { somites, optic and otic vesicles, Kupffer's vesicle in regression, pigmentation } \\
\text { of embryo body and attached tail. }\end{array}$ \\
\hline 9.00 & Organogenesis & Late segmentation phase - 19 somites, optic vesicle, otic vesicles, pigmentation of embryo body and free tail. \\
\hline 10.00 & & Late segmentation phase - 24 somites, free tail, optic and otic vesicles and pigmentation of embryo body. \\
\hline 11.00 & & Late segmentation phase - More than 30 somites, growing larva, pre-hatching, pigmentation of the yolk \\
\hline 12.00 & & membrane close to the head and tail. \\
\hline 13.00 & Hatching & $100 \%$ hatched larvae. \\
\hline
\end{tabular}



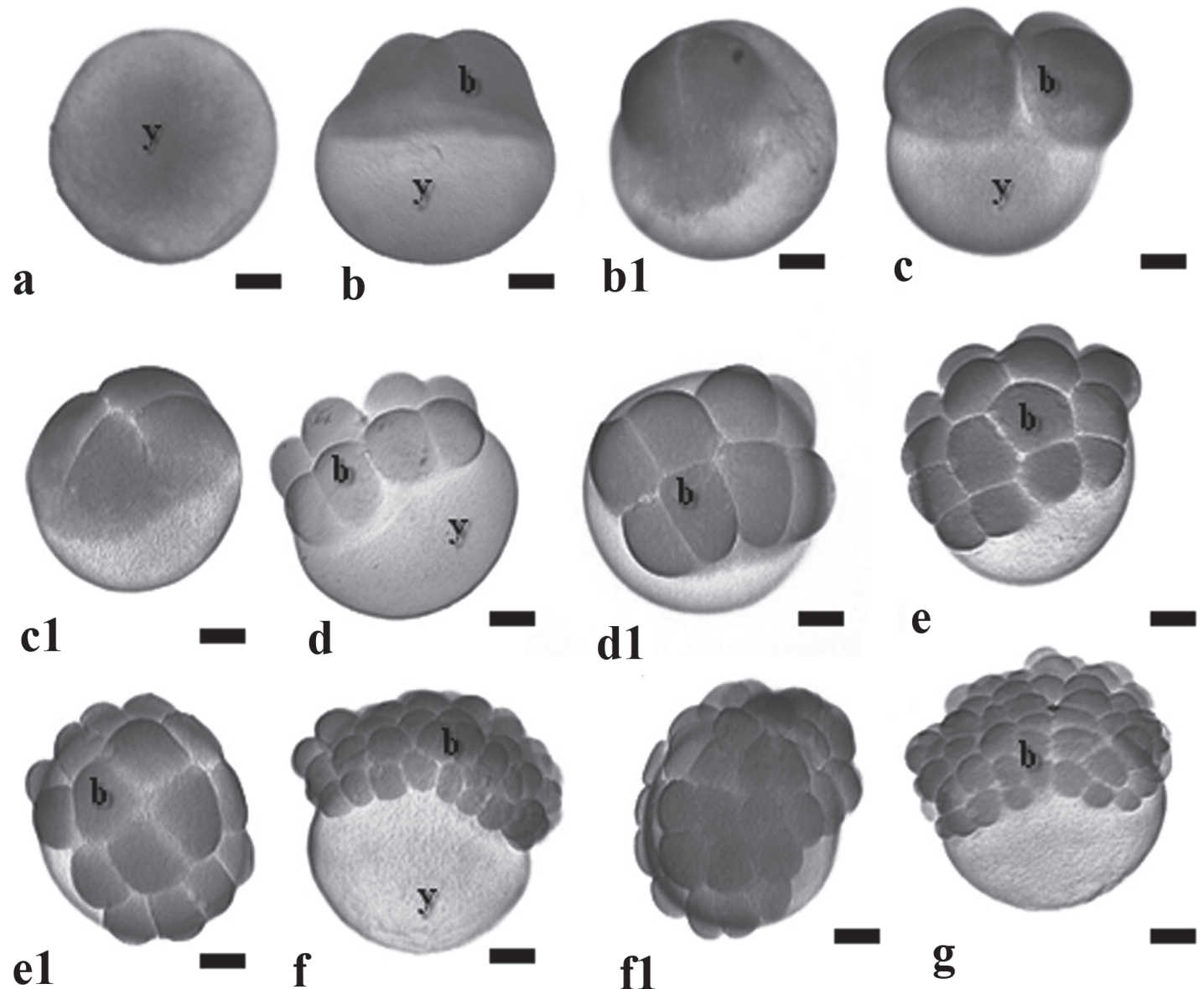

e1
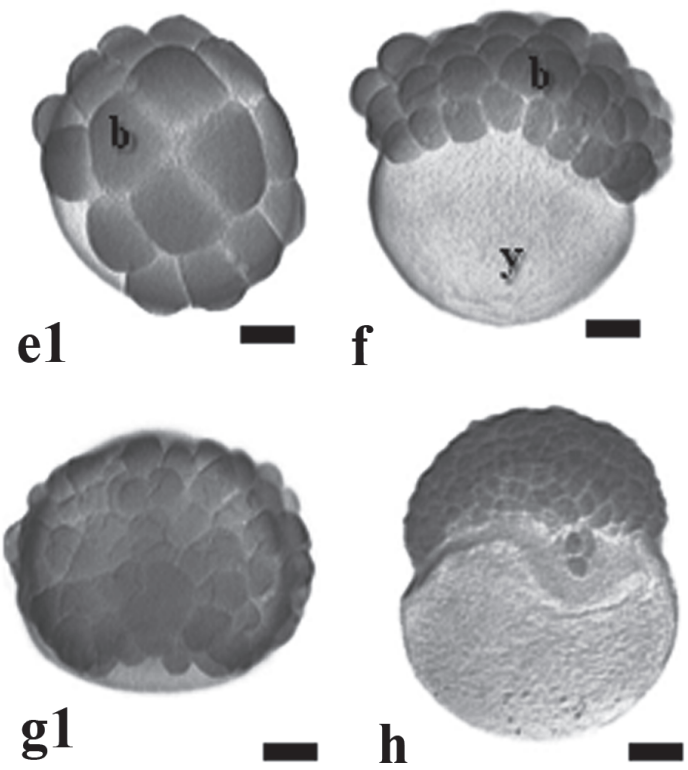

f1
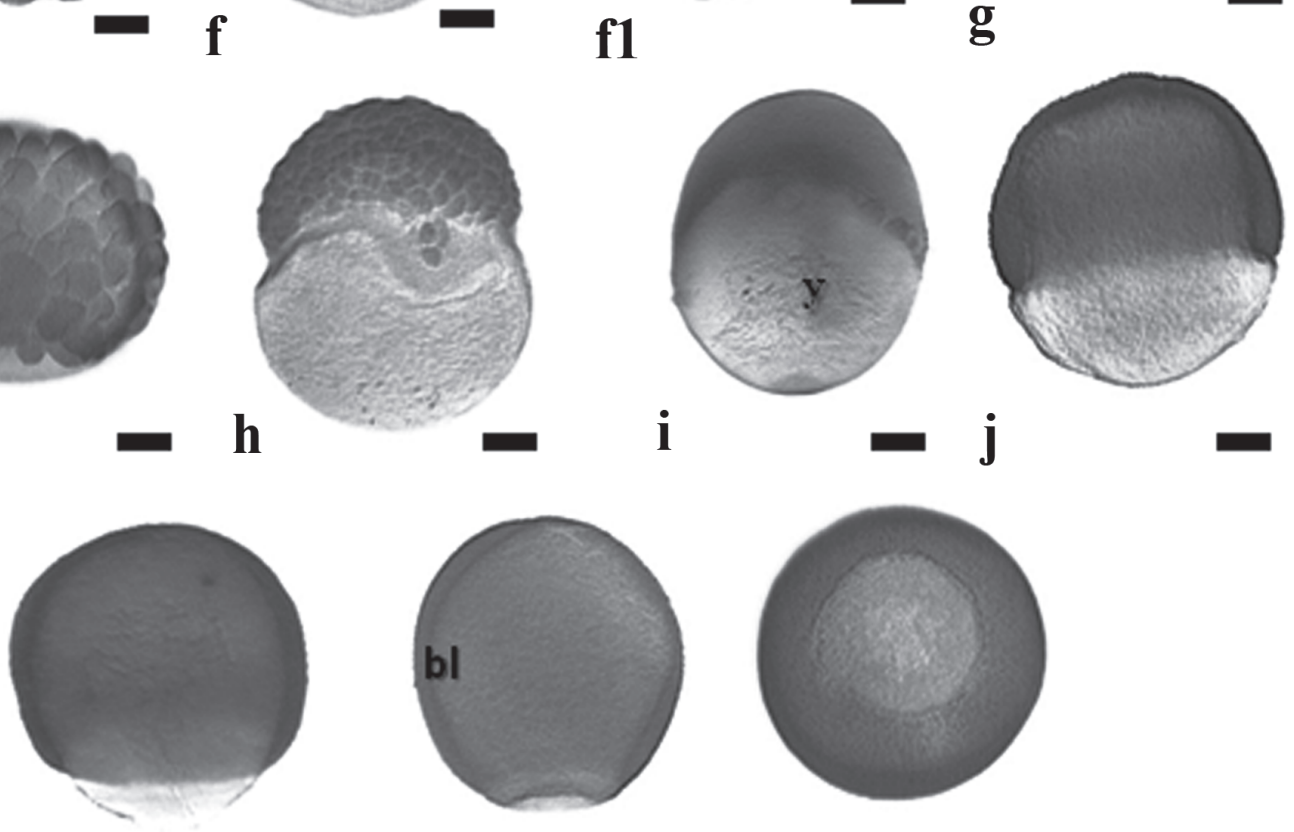

$\mathbf{k}$

I

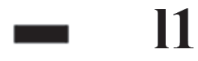

Fig. 1. Embryonic development stages zygote, cleavage and gastrula in the Pimelodus maculatus. a - post-fertilization without chorion; $\mathbf{b}$ and b1 - 2-cell embryos; $\mathbf{c}$ and $\mathbf{c 1}$ - 4-cell embryos; $\mathbf{d}$ and d1- 8-cell embryos; $\mathbf{e}$ and $\mathbf{e 1}$ - 16-cell embryos; $\mathbf{f}$ and f1 - 32-cell embryos; $\mathbf{g}$ and $\mathbf{g 1}$ - 64-cell embryos; $\mathbf{h}$ - morula; $\mathbf{i}$ - gastrula ( $25 \%$ of epiboly); $\mathbf{j}$ - gastrula ( $50 \%$ of epiboly); $\mathbf{k}$ gastrula (75\% of epiboly); $\mathbf{l}$ - gastrula ( $90 \%$ of epiboly); $\mathbf{1 1}$ - detail of the blastopore closure. Staining: HE. y: yolk, b: blastomeres, bl: blastoderm. Scale bar: $81 \mu \mathrm{m}$. 
Table 2. Embryonic development of Pimelodus maculatus, at $25^{\circ} \mathrm{C}$.

\begin{tabular}{|c|c|c|}
\hline Time (hours) & Stage & Observations \\
\hline $0-0.42$ & Zygote & Definition of animal and vegetal poles \\
\hline 0.50 & Cleavage & $100 \%$ with 2 cells \\
\hline 0.67 & Cleavage & $44 \%$ with 2 cells and $56 \%$ with 4 cells \\
\hline 0.75 & Cleavage & $100 \%$ with 4 cells \\
\hline 0.83 & Cleavage & $67 \%$ with 4 cells and $33 \%$ with 8 cells \\
\hline 0.91 & Cleavage & $80 \%$ with 8 cells and $20 \%$ with 4 cells \\
\hline 1.00 & Cleavage & $30 \%$ with 4 cells, $33 \%$ with 8 cells and $37 \%$ with 16 cells \\
\hline 1.17 & Cleavage & $3 \%$ with 4 cells, $46 \%$ with 8 cells, $8 \%$ with 16 cells and $43 \%$ with 32 cells \\
\hline 1.34 & Cleavage & $19 \%$ with 16 cells, $50 \%$ with 32 cells and $31 \%$ with 64 cells \\
\hline 1.51 & Cleavage & $16 \%$ with 32 cells and $84 \%$ with 64 cells \\
\hline 1.68 & $\begin{array}{l}\text { Cleavage } \\
\text { Blastula } \\
\text { Gastrula }\end{array}$ & $41 \%$ with 64 cells, $43 \%$ at morula, $16 \%$ in epiboly of $25 \%$ \\
\hline 1.85 & $\begin{array}{l}\text { Cleavage } \\
\text { Blastula } \\
\text { Gastrula }\end{array}$ & $25 \%$ with 64 cells, $56 \%$ at morula and $19 \%$ in epiboly of $25 \%$ \\
\hline 2.00 & $\begin{array}{l}\text { Blastula } \\
\text { Gastrula }\end{array}$ & $86 \%$ at morula and $14 \%$ in epiboly of $25 \%$ \\
\hline 3.00 & $\begin{array}{l}\text { Blastula } \\
\text { Gastrula }\end{array}$ & $80 \%$ at morula and $20 \%$ in epiboly of $25 \%$ \\
\hline 4.00 & Gastrula & $56 \%$ in epiboly of $50 \%, 26 \%$ in epiboly of $75 \%$ and $18 \%$ in epiboly of $25 \%$ \\
\hline 5.00 & Gastrula & $32 \%$ in epiboly of $50 \%$ and $68 \%$ in epiboly of $75 \%$ \\
\hline 6.00 & Gastrula & $100 \%$ in epiboly of $90 \%$ \\
\hline 7.00 & $\begin{array}{l}\text { Gastrula } \\
\text { Organogenesis }\end{array}$ & $6 \%$ in epiboly of $90 \%$ and $94 \%$ early segmentation phase \\
\hline 8.00 & & Early segmentation phase $-6 \%$ at neurula and $94 \%$ with attached tail, optic vesicle, 5 somites and Kupffer's vesicle \\
\hline 9.00 & & Early segmentation phase - 12 somites, beginning of body pigmentation, Kupffer's, optic vesicle, attached tail \\
\hline 10.00 & & Early segmentation phase - 20 somites, otic, optic and Kupffer's vesicles, attached tail, pigmentation of embryo body \\
\hline 11.00 & & $\begin{array}{l}\text { Late segmentation phase - Free tail, absence of Kupffer's vesicle, } 24 \text { somites, otic and optic vesicles, pigmentation of } \\
\text { embryo body }\end{array}$ \\
\hline 12.00 & Organogenesis & Late segmentation phase - Free tail, more than 30 somites, otic and optic vesicles, pigmentation \\
\hline 13.00 & & Late segmentation phase - Free tail, more than 35 somites, pigmentation, loose chorion \\
\hline 14.00 & & $\begin{array}{l}\text { Late segmentation phase - More than } 40 \text { somites, increased pigmentation at head and tail, free tail, otic and optic } \\
\text { vesicles }\end{array}$ \\
\hline 15.00 & & $90 \%$ at pre-hatching and $10 \%$ hatched. \\
\hline 16.00 & Hatching & $62 \%$ pre-hatching and $38 \%$ hatched \\
\hline 17.00 & & $100 \%$ hatched larvae \\
\hline
\end{tabular}

Cleavage stage. $0.40-2.00 \mathrm{~h}\left(29^{\circ} \mathrm{C}\right) ; 0.50-1.85 \mathrm{~h}\left(25^{\circ} \mathrm{C}\right)$

Twenty-four minutes after fertilization at $29^{\circ} \mathrm{C}$ and 30 minutes at $25^{\circ} \mathrm{C}$, the first cleavages could be noticed initiating from the center towards the blastodisc margins (Fig. 1b1). In Pimelodus maculatus, the type of cleavages are discoid meroblastic (Figs. 5a-b), i.e., they occur in the animal pole according to the following pattern: first cleavage was vertical, originating two blastomeres (Figs. 1b-b1), the second cleavage was vertical and perpendicular to the first one, giving rise to four blastomeres (Figs.1c-c1); the third cleavage was vertical and parallel to the first one, originating 8 blastomeres (Figs. 1dd1), under a $4 \times 2$ arrangement; the forth cleavage was vertical and parallel to the second one, producing 16 blastomeres in a $4 \times 4$ formation (Figs.1e-e1); the fifth cleavage was vertical and parallel to the first one, giving rise to 32 blastomeres in a $4 \times 8$ formation (Figs.1f-f1); the sixth cleavage was horizontal, forming two cell layers with a total of 64 blastomeres in a $2 \times 4 \times 8$ formation (Figs.1g-g1), i.e., the embryo presents two cell layers where the superior layer has undergone complete cleavage. For as long as the cleavage continues, the number of blastomeres increases and their size diminishes. Until the third cleavage the cells were homogeneous, but from the fourth cleavage plane onwards blastomeres of distinct sizes could be observed. At this embryonic stage, individualized nuclei were undetectable (Figs.5b-c), but several yolk globules could be visualized in the cytoplasm (Fig.5a).

The morula phase was characterized by a blastoderm with more than 64 cells, forming a "half-berry' like cell mass (Fig. 1h). It was also possible to observe at this stage, the beginning of the formation of the yolk syncyctial layer, named periblast (Fig. 5d).

The yolk syncyctial layer (YSL) of Pimelodus maculatus embryos is characterized by a cytoplasm layer with several nuclei, containing yolk globules within the cytoplasm. The nuclei in this layer are initially from the nearby blastomeres that, when in contact with the cytoplasm layers encompassing the yolk, release their contents into it.

Image analyses indicate the yolk globules penetrate the YSL as fragmented portions, and then they are particularized and transferred to the blastomeres where the yolk globules are remounted (Figs. 6a-b).

Blastula stage. $1.68-3.00 \mathrm{~h}\left(25^{\circ} \mathrm{C}\right) ; 1.75-2.00 \mathrm{~h}\left(29^{\circ} \mathrm{C}\right)$

At the beginning of this stage, the blastoderm presented 


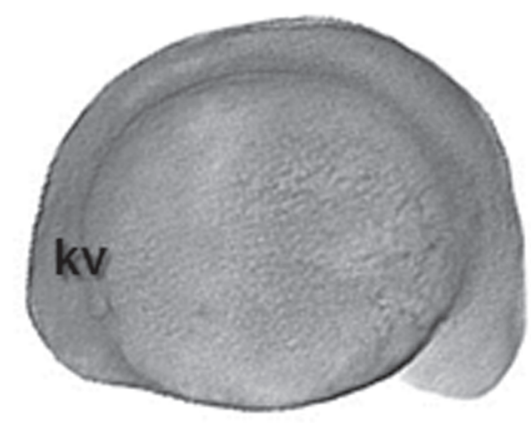

$\mathbf{a}$
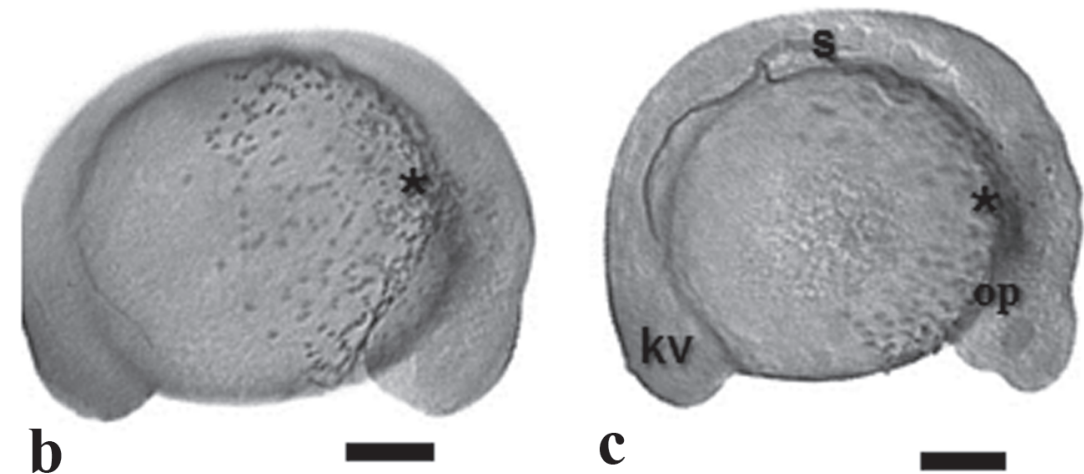
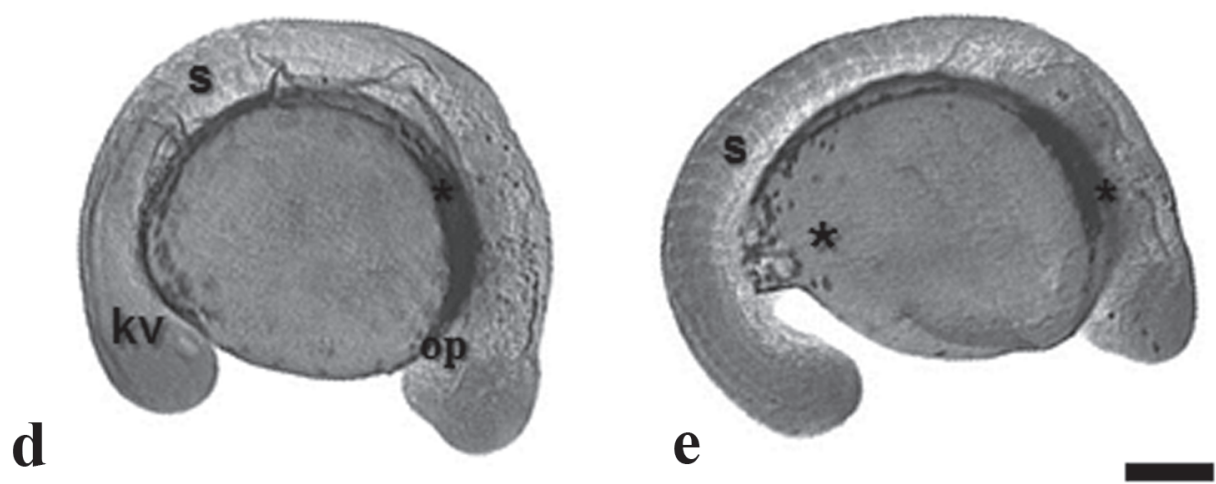

Fig. 2. Pimelodus maculatus embryos in segmentation stage: a - neurula; $\mathbf{b}$ - embryo with about 11 somites, optic vesicle, attached tail and pigmentation of embryo body; $\mathbf{c}$ - embryo with about 14 somites, optic and Kupffer's vesicles, pigmentation of embryo body and attached tail; d - embryo with about 19 somites, Kupffer's, optic and otic vesicles, attached tail e pigmentation of embryo body; e - 24 somites, presence of otic and optic vesicles, Kupffer's vesicle is absent and free tail. Staining: HE. asterisks: evolution of body pigmentation in embryo; op: optic vesicle; kv: Kupffer's vesicle; s: somites. Scale bars: a: $82 \mu \mathrm{m} ; \mathbf{b}: 81.4 \mu \mathrm{m} ; \mathbf{c}: 80.4 \mu \mathrm{m} ; \mathbf{d}: 81.3 \mu \mathrm{m} ; \mathbf{e}: 81.1 \mu \mathrm{m}$.

a cup-like shape. The cells were still dividing but the cleavage planes were undetermined. The main characteristic of this stage is the appearance of irregular spaces among the blastomeres - the pseudoblastocoel. The end of this stage was characterized by the first epiboly movements (Figs. 5d and 6a-d).

Gastrula stage. $2.25 \mathrm{~h}-5.00 \mathrm{~h}\left(29^{\circ} \mathrm{C}\right) ; 1.68 \mathrm{~h}-7.00 \mathrm{~h}\left(25^{\circ} \mathrm{C}\right)$

The gastrula stage was characterized by the occurrence of morphogenetic movements - epiboly, convergence and cell involution (Figs. 1i-j-k-1), that ultimately will form the first germinative follicles and determine the embryonic axis.

During epiboly, the yolk syncyctial layer expands along with the embryo until recover all the yolk mass, forming the yolk plug. The periblast gives rise to a fringe in front of the blastoderm border, since its formation up to blastopore closure (Figs. 6c-e-f and 7a-b). The morphogenetic movements of convergence and cell involution (or migration) started from the blastoderm border at about $50 \%$ of epiboly, forming the germination ring or the embryonic shield, and finished with the formation of two embryonic layers, the epiblast and the hypoblast (Fig. 7c).
This stages ends when the yolk plug is completely closed.

Organogenesis stage. $6.00-12.00 \mathrm{~h}\left(29^{\circ} \mathrm{C}\right) ; 7.00-14.00 \mathrm{~h}\left(25^{\circ} \mathrm{C}\right)$

Early segmentation phase. $6.00-8.00 \mathrm{~h}\left(29^{\circ} \mathrm{C}\right) ; 8.00-10.00 \mathrm{~h}\left(25^{\circ} \mathrm{C}\right)$

This phase lasted from the sixth up to the eighth hour at $29^{\circ} \mathrm{C}$ and from seventh to tenth hour at $25^{\circ} \mathrm{C}$. At this stage, the optic vesicle was present (Figs. 2c-e and 7e), as well as the Kupffer's vesicle (Figs. 2a-c-d and 7f), the notochord (Figs. $7 \mathrm{~d}$ and $8 \mathrm{~b}$ ), and the somites that have a mesoderm origin and will give rise to the muscles (Figs. 8a-b). The tail is short and attached to the yolk sac, which is pigmented at the cephalic and caudal extremities due to the presence of punctiforme chromatophores (Figs. 2c-d).

During segmentation, the yolk syncyctial layer becomes a thin layer encompassing the yolk completely (Fig. 7d), the neural tube begins to be formed (Fig. 8b) and, as long as its sections undergo differential growth, the prosencephalon, mesencephalon and rhombencephalon regions can be identified.

The Kupffer's vesicle, whose function remains unknown, disappeared after nine hours at $29^{\circ} \mathrm{C}$ and 11 hours at $25^{\circ} \mathrm{C}$, 


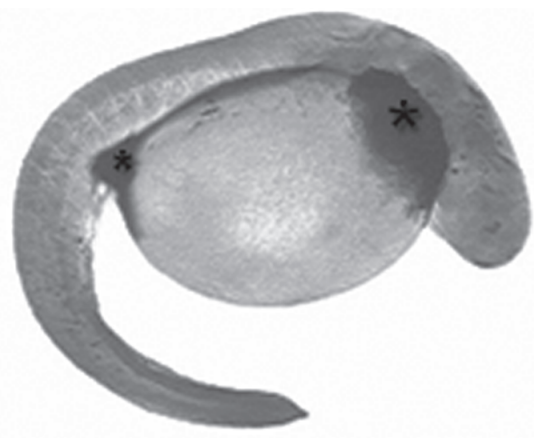

$\mathbf{a}$
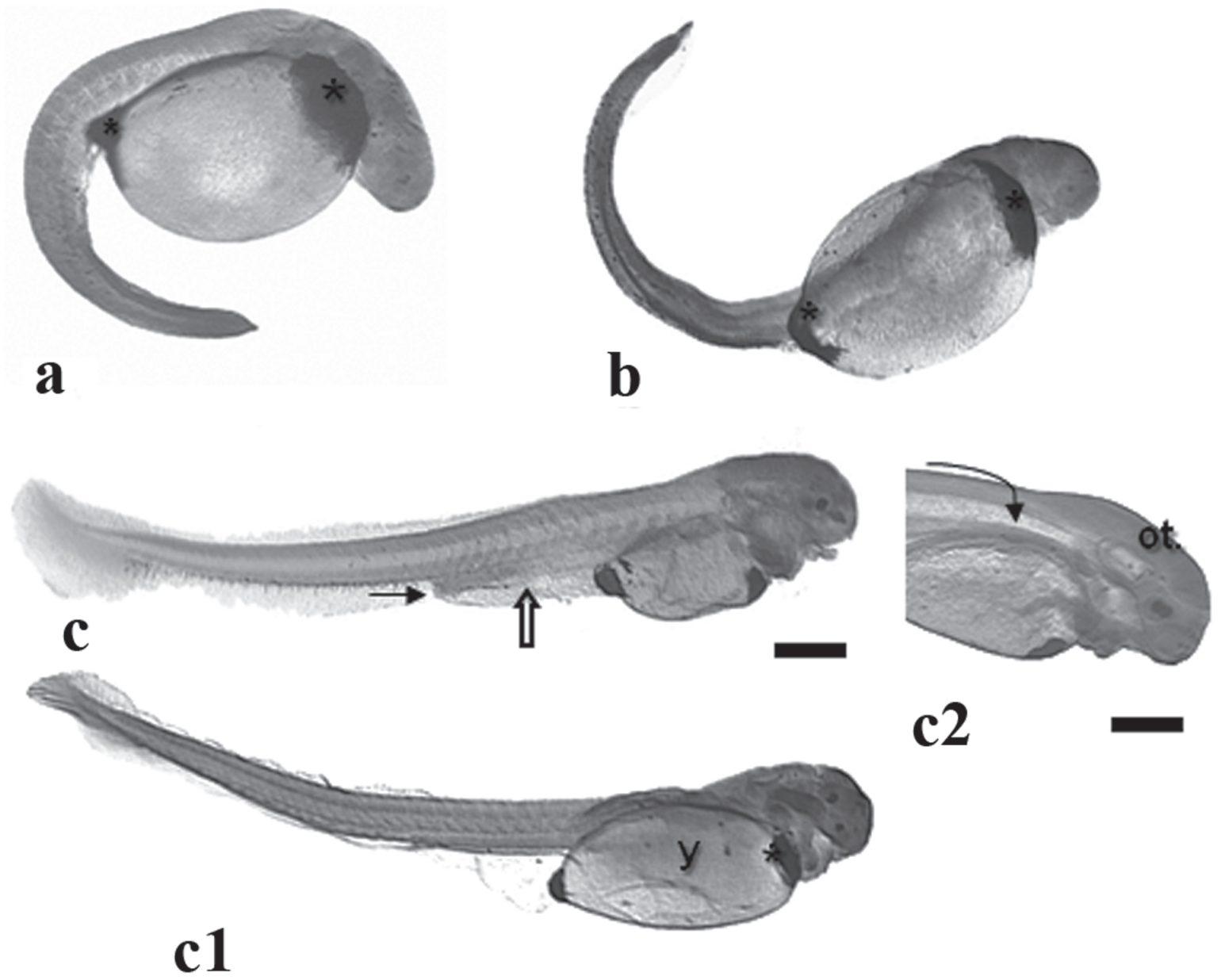

Fig. 3. Pimelodus maculatus embryos in organogenesis (late segmentation phase) and hatching stage. a - more than 30 somites, growing larva; b - pre-hatching embryo; $\mathbf{c}, \mathbf{c 1}$ and $\mathbf{c 2}$-hatched larvae. $\mathbf{C 2}$ - detail of the otic vesicle and notochord. Staining: HE. asterisks: pigmentation close to head and tail; black arrow: anus; large arrow: posterior intestine; ot : otic vesicle; black curved arrow: notochord; y: yolk. Scale bars: a: $81 \mu \mathrm{m}$; b: $81 \mu \mathrm{m}: \mathbf{c}: 110 \mu \mathrm{m} ; \mathbf{c 1}: 81 \mu \mathrm{m} ; \mathbf{c} 2: 110.4 \mu \mathrm{m}$.

during the neurula phase. Some embryos from this stage on presented an unidentified structure within the yolk syncyctial layer, below the embryo body, that resembles a tube but lacks any delimited membrane (Fig. 7f).

This stage ends with the tail detachment and growth (Fig. 2e).

Late segmentation phase. $9.00-12.00 \mathrm{~h}\left(29^{\circ} \mathrm{C}\right) ; 11.00-14.00 \mathrm{~h}$ $\left(25^{\circ} \mathrm{C}\right)$

Started at the $12^{\text {th }}$ hour and lasted up to $14^{\text {th }}$ hour at both $29{ }^{\circ} \mathrm{C}$ and $25^{\circ} \mathrm{C}$, being characterized by the presence of a free tail, more than 30 somites and embryo growth (Fig.3).

At this phase, the embryos presented a well developed otic vesicle (Fig. 9a), the notochord extends from the cephalic up to caudal region (Fig. 8c), the posterior intestine developed from the endoderm, reaching the urogenital pore and the intestinal lumen can be observed (Figs. 8d and 9e). The somites are undergoing myogenesis to eventually form the muscles (Figs. 8e-f).

The chromatophores that were located at the edges of the yolk sac started migrating and now can be observed in several parts of the embryo body. They are also changing from a punctiforme a dendritic morphology (Figs. 9c-f).

\section{Hatching stage. $13.00 \mathrm{~h}\left(29^{\circ} \mathrm{C}\right) ; 17.00 \mathrm{~h}\left(25^{\circ} \mathrm{C}\right)$}

At this stage, the embryos presented a mean total length of $3410 \mu \mathrm{m}$ (Fig. 3c) and vigourus movements that are important to break the chorion, more flexible now.

At hatching, the somite myogenesis was quite advanced (Fig. 9b), and heart beats could be clearly noticed in vivo. Under histological cuts, the hearts is evident (Fig. 9d), the mouth is closed once the digestive system is under 

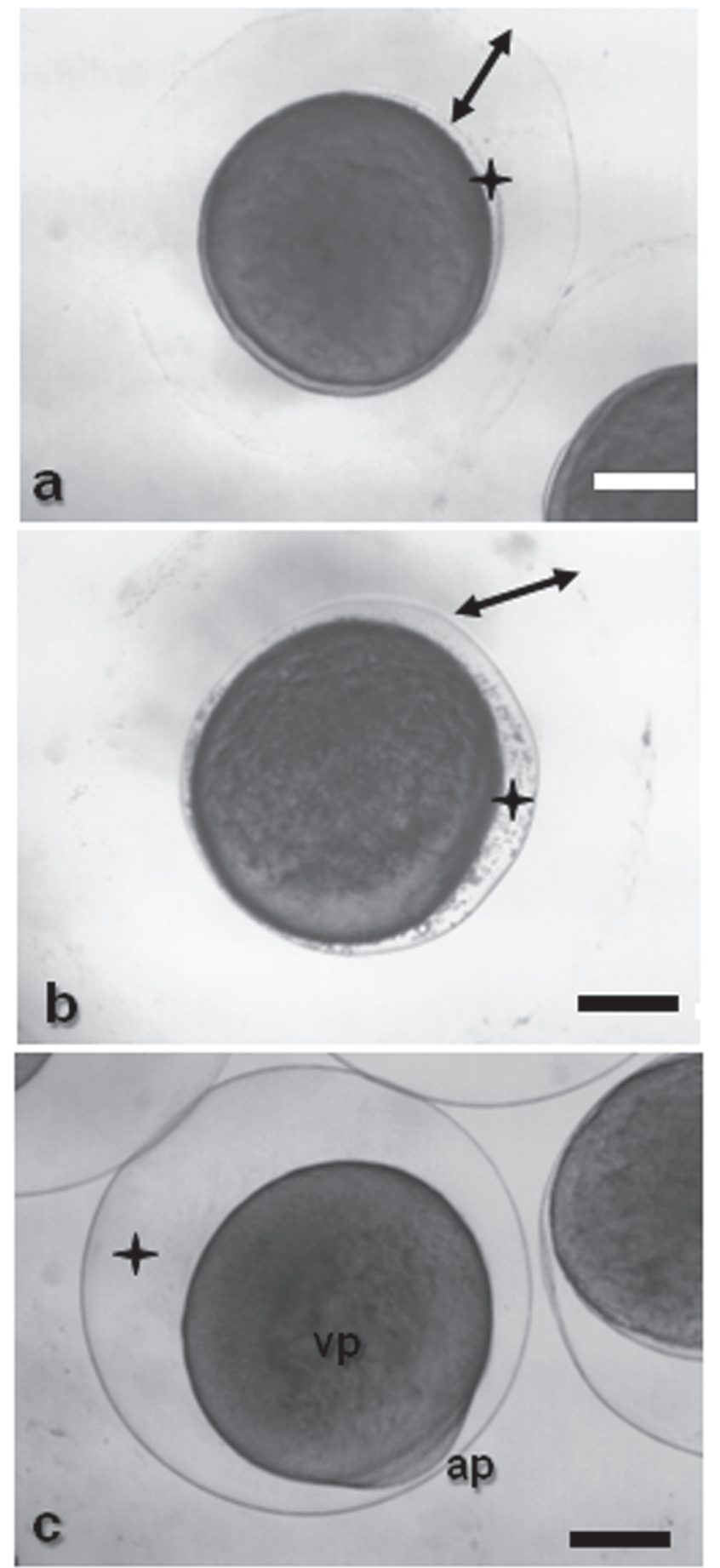

Fig. 4. Pimelodus maculatus egg. a - fertilized and non-hydrated egg; b - hydrating egg and c - hydrated egg. star: perivitelline space; double arrow: gelatinous layers; vp: vegetal pole; ap: animal pole. Scale bars: a: $75 \mu \mathrm{m}$; b: $868 \mu \mathrm{m}$; c: $1100 \mu \mathrm{m}$.

development, the eyes are intensively pigmented, the chromatophores are spread over several body parts, and the cephalic structures are well developed and defined (Figs. $8 d$ and $9 a-e)$.

The tube-like structure formerly seen within the YSL remains up to late segmentation phase, composing a single structure at the cephalic and caudal ends and double at the dorsal region (Figs. 8b-f-h).

\section{Discussion}

The morphological events identified during the embryogenesis of Pimelodus maculatus, as well as the short duration of embryonic development, were similar to those reported in other teleosts: Brycon orbignyanus (Ganeco, 2003), Prochilodus lineatus (Ninhaus-Silveira et al., 2006), Pseudoplatystoma coruscans (Marques et al., 2008, Landines et al., 2003).

In this present study, after fertilization, egg hidratation was observed, which lead to a increase of its volume. The morphometric values of Pimelodus maculatus eggs were similar to those obtained by Luz et al. (2001), $900 \pm 20 \mu \mathrm{m}$ for nonhydrated eggs e $1090 \pm 10 \mu \mathrm{m}$ for hydrated ones at temperature the $23.1 \pm 0.5^{\circ} \mathrm{C}$, but lower to those reported by Sato (1999); 1050 to $1200 \mu \mathrm{m}$ (non-hydrated) and 1730 to $1950 \mu \mathrm{m}$ (hydrated eggs) at temperature between 24 and $25^{\circ} \mathrm{C}$. Species such as Prochilodus lineatus (Ninhaus-Silveira et al., 2006), have eggs with a large perivitelline space that protects the embryo against injuries during embryogenesis, contributing to improved survival in running water. In Rhamdia hilarii eggs, the perivitelline space has been reduced (Godinho et al., 1978), as was also observed in Pimelodus maculatus eggs, after hydration of the eggs. Taking into account the functions assigned to the chorion and the perivitelline space, such as mechanical protection, osmotic regulation, fluctuating, nutrition and prevention of polyspermy (Shardo, 1995), this difference in size of the perivitelline space occurs due to different reproductive strategies of species above mentioned and the environment in which eggs develop. The yellowish colour is characteristic of the oocytes of Siluriformes (Sato et al., 2003; Marques et al., 2008) and is associated with the presence of carotenoid pigments obtained from food. These pigments constitute an endogenous oxygen supply when the respiratory system is inefficient at obtaining exogenous oxygen (Balon, 1977; Amorim et al., 2009 apud Perini et al., 2010).

The gelatinous layer surrounding the oocytes and the eggs of the Pimelodus maculatus provided some adherence to them, as observed in Rhamdia hilari (Godinho et al., 1978), Pseudoplatystoma coruscans (Landines et al., 2003), Rhinelepis aspera (Perini et al., 2010) and in surubins hybrids (Pseudoplatystoma corruscans x Pseudoplatystoma fasciatum) (Faustino et al., 2007). According to Rizzo et al. (2002), this gelatinous layer found in Siluriformes is composed of a net of several delicate fibrils, being observed in either adhesive or non-adhesive eggs, such as those from Pimelodus maculatus, as well as in eggs from other teleosteans like Perciformes, Cypriniformes and Cyprinodontiformes (Riehl \& Patzner, 1998). More studies concerning the constitution and function of the jelly coat and therelationship between egg surface and adhesiveness are necessary.

The egg cleavages in Pimelodus maculatus occurred only 

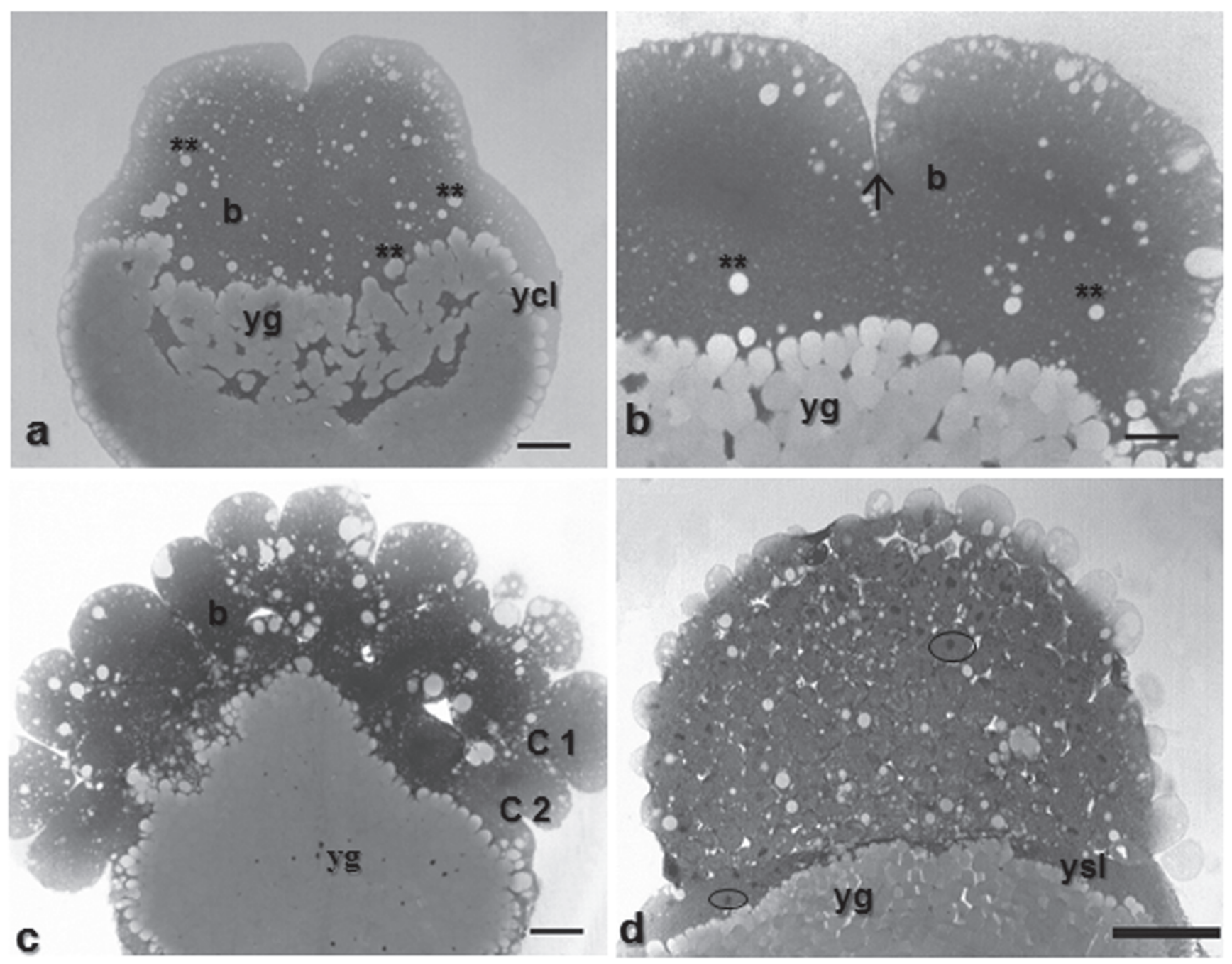

Fig. 5. Histologicals sections of Pimelodus maculatus embryos in cleavage stage. a - with 2 cells, staining: HE, showing details of the yolk globules penetration into embryo; $\mathbf{b}$ - with 16 cells, staining: toluidine blue, showing detail of the meroblastic division; c - visualization of the penetration of yolk globules in blastomeres, first complete and partial second cleavages, staining: toluidine blue; $\mathbf{d}$ - morula phase, staining: HE, characterized by the formation of the yolk syncyctial layer and individualized nuclei. b: blastomeres; ycl: yolk cytoplasm layer; yg: yolk globules; two asterisks: penetration of yolk globules in the embryo; arrow: partial or meroblastic division; $\mathrm{C} 1$ : total cleavage; $\mathrm{C} 2$ : partial cleavage; ysl: yolk syncyctial layer; circle: individualized nucleus. Scale bars: a: $210 \mu \mathrm{m}$; b: $83.8 \mu \mathrm{m}$; c: $83.8 \mu \mathrm{m}$; d: $526.4 \mu \mathrm{m}$; e: $42.6 \mu \mathrm{m}$.

in the animal pole, while the vegetative pole was composed of yolk. Such division pattern is typical of fish eggs and it is known as meroblastic or partial, once it involves exclusively the animal pole (Balinsky, 1970; Leme dos Santos \& Azoubel, 1996). The mitotic divisions during the cleavage take place in order to promote a new balance in the relationship between the nucleus and the cytoplasm, i.e., the high volume of the zygote cytoplasm is divided into increasingly smaller cells, while the cytoplasm volume does not increase (Gilbert, 2003). This feature was visualized in Pimelodus maculatus: as the number of blastomeres increased, their size decreased corroborating the reports by Ganeco (2003), Nakagui et al. (2006) and Castellani et al. (1994), being possible to observe several events of mitotic divisions. Ninhaus-Silveira et al. (2006) reported that the yolk globules were fragmented during the cleavage stage, what is likely to facilitate their absorption by the cells, thus corroborating the observations in Pimelodus maculatus.

Kimmel et al. (1995) and Morrison et al. (2001) reported that even within the same spawn and incubation at optimal conditions, the period of embryonic development shows asynchrony. Analyzing the abovementioned results, it can be shown that the morphological changes during embryogenesis, besides being species-specific, are closely related to temperature variation. At higher temperatures, the incubation time is shortened, while, at lower temperatures, this period is increased. In the present study with Pimelodus maculatus, 

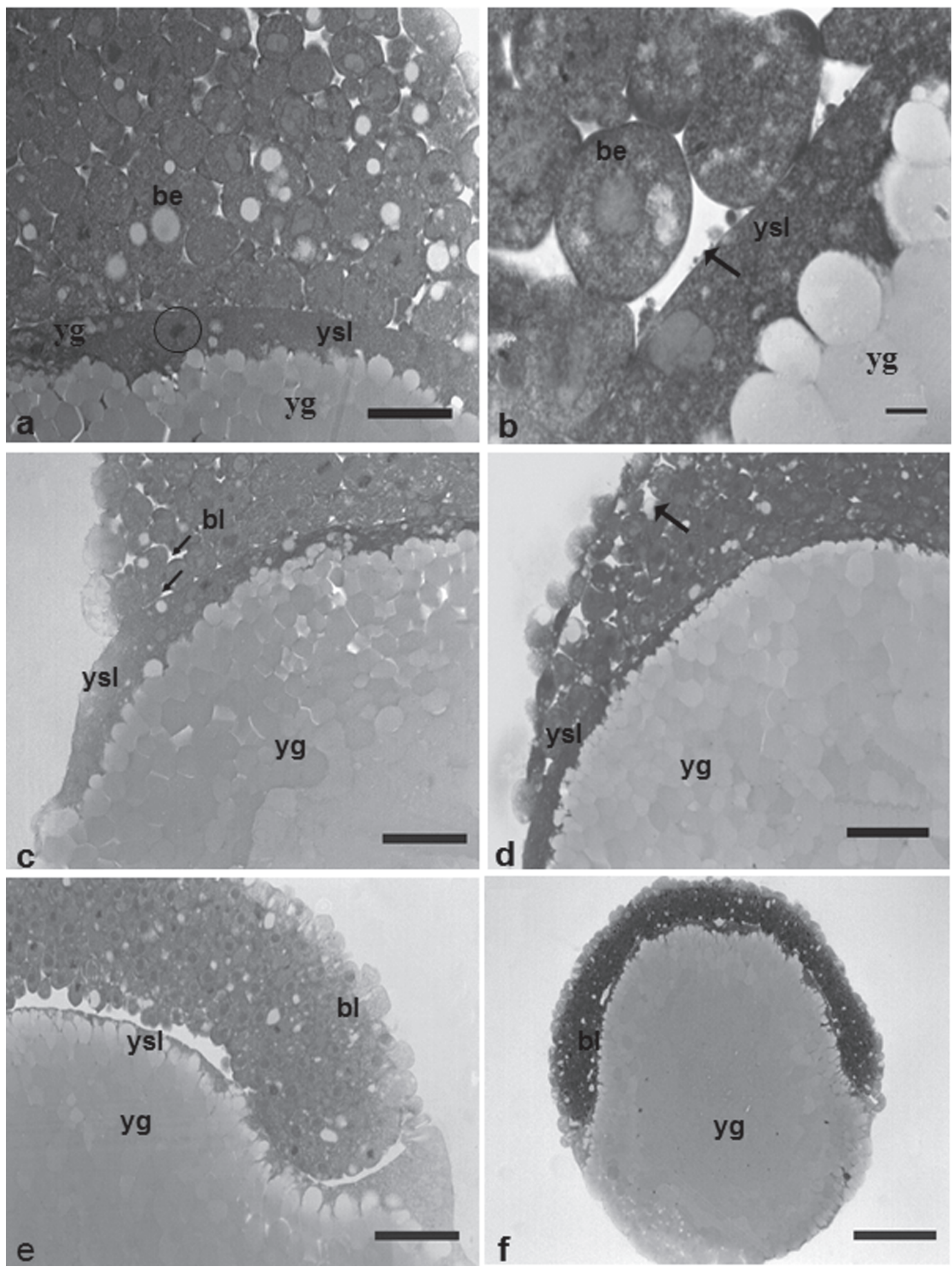

Fig. 6. Histologicals sections of Pimelodus maculatus embryos. a- detail of the nucleus of the syncyctial layer, at morula phase, staining: HE; $\mathbf{b}$ - detail of the penetration of yolk globules as fragments into the yolk syncyctial layer, staining: HE; c- embryo section at blastula stage, initiating epiboly, staining: toluidine blue; d- embryo section at gastrula stage (epiboly of $25 \%$ ), expansion of yolk syncyctial layer along with the embryo to form the yolk plug, staining: toluidine blue; $\mathbf{e}$ - embryo section at gastrula stage (epiboly of 25\%), staining: HE. f - embryo section at gastrula stage (epiboly of 50\%), staining: toluidine blue; ysl: yolk syncyctial layer; be: blastomeres with euchromatic nucleus; circle: presence of nucleus in the yolk syncyctial layer; yg: yolk globules; bl: blastoderm; black arrows: irregular spaces; bl: blastoderm. Scale bars: a: $68.2 \mu \mathrm{m} ; \mathbf{b :}$ $65.6 \mu \mathrm{m} ; \mathbf{c}: 52.5 \mu \mathrm{m} ; \mathbf{d}: 52.5 \mu \mathrm{m} ; \mathbf{e :} 83.8 \mu \mathrm{m}$ f: $210 \mu \mathrm{m}$. 

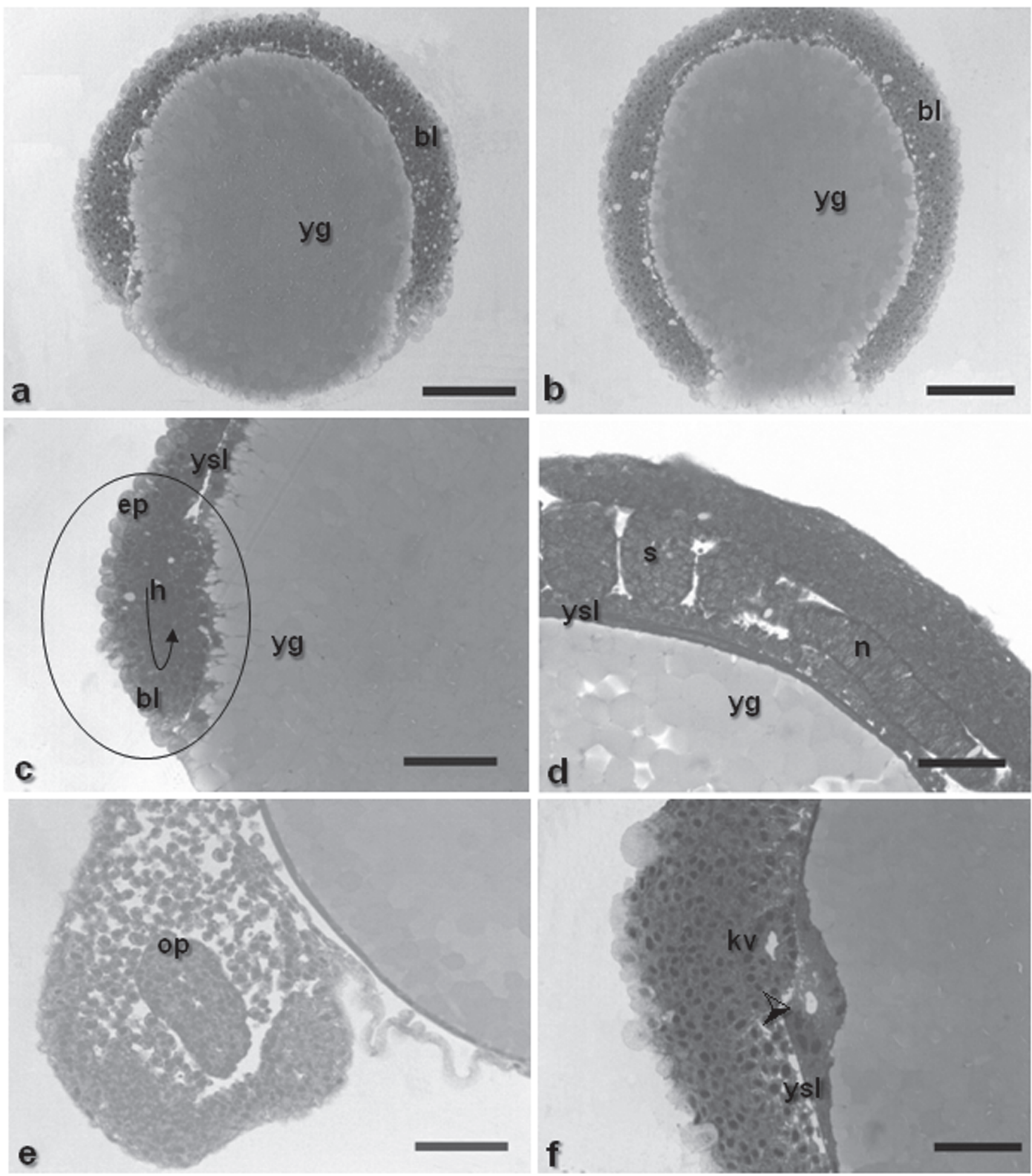

Fig. 7. a - embryo section at gastrula stage (epiboly of 75\%), staining: HE; b - embryo section at gastrula stage (epiboly of 90\%), blastopore closure. Staining: HE; c - embryo section at gastrula stage (epiboly of 50\%), staining: toluidine blue. d neurula phase, with details of somites and notochord, staining: toluidine blue; $\mathbf{e}$ - neurula phase, with details of the optic vesicle, staining: HE. f - neurula phase, with details of the Kupffer's vesicle and unidentified structure. Staining: HE. yg: yolk globules in the embryo; bl: blastoderm; ysl: yolk syncyctial layer; s: somites; n: notochord; circle and black arrow: embryonic shield; ep: epiblast; h: hypoblast; op: optic vesicle; kv: Kupffer's vesicle; ysl: yolk syncyctial layer; arrowhead: unidentified structure. Scale bars: a: $210 \mu \mathrm{m} ; \mathbf{b :} 210 \mu \mathrm{m} ; \mathbf{c :}: 106.6 \mu \mathrm{m} ; \mathbf{d}: 52.5 \mu \mathrm{m} ; \mathbf{e :}: 83.8 \mu \mathrm{m} ; \mathbf{f :} 52.5 \mu \mathrm{m}$. 

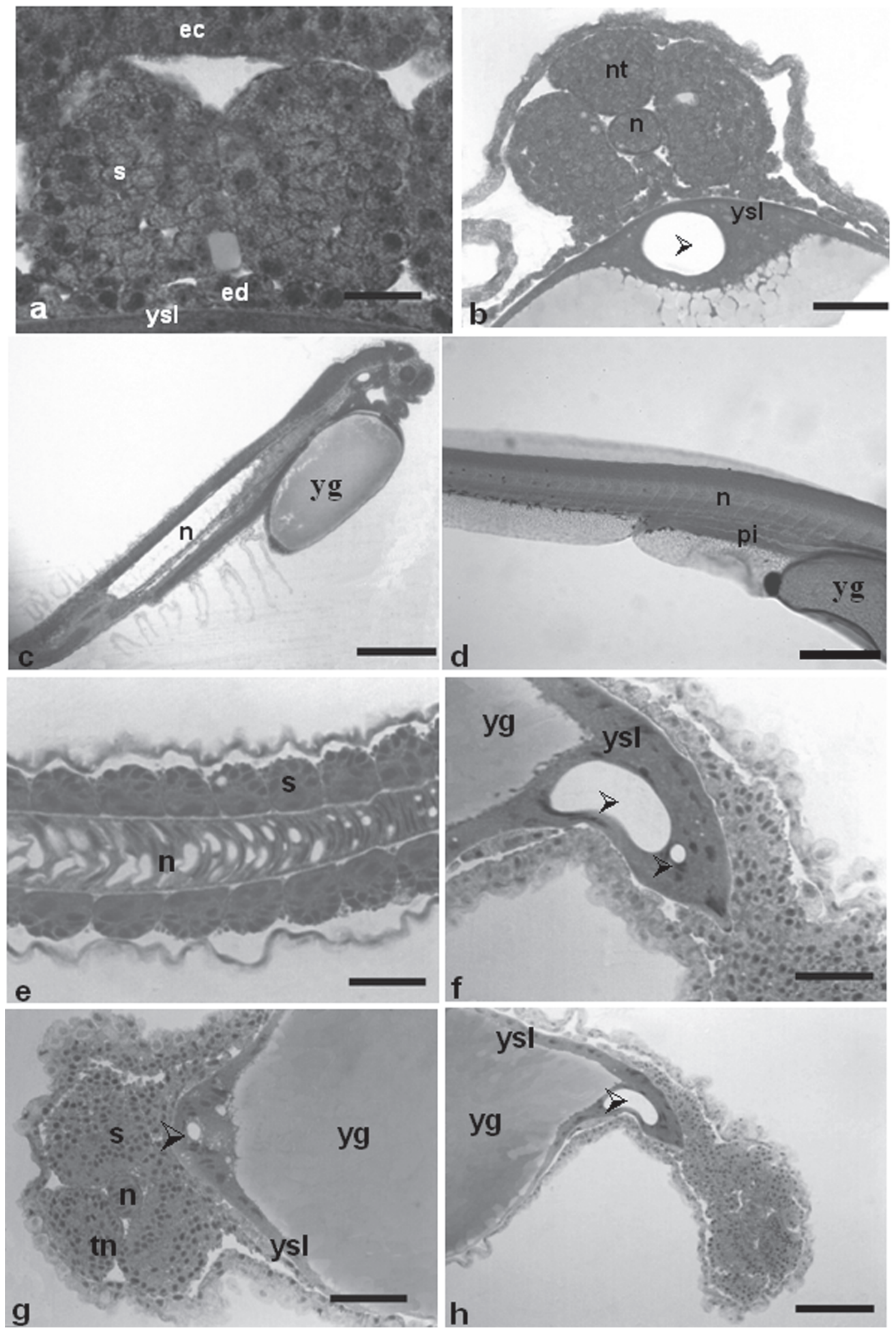

Fig. 8. a - segmentation stage, showing the somites that will form the muscles; $\mathbf{b}$ - segmentation stage with formation of the neural tube; c - overall detail of the embryo, highlighting the notochord; d- posterior intestine under development; e development of notochord up to caudal region, presence of somites; $\mathbf{f}$ - unidentified double structure across the yolk syncyctial layer; $\mathbf{g}$ - unidentified structure in the yolk syncyctial layer; $\mathbf{h}$ - unidentified single structure across the yolk syncyctial layer. Staining: HE. ec: ectoderm; ed: endoderm; ysl: yolk syncyctial layer; s: somites; nt: neural tube; n: notochord; arrowhead: unidentified structure; pi: posterior intestine; yg: yolk globules in the embryo. Scale bars: a: $20.8 \mu \mathrm{m}$; b: $65.6 \mu \mathrm{m} ; \mathbf{c}: 139.3 \mu \mathrm{m}$; d: $100 \mu \mathrm{m} ; \mathrm{e:}: 42.6 \mu \mathrm{m} ; \mathbf{f :} 68.2 \mu \mathrm{m} ; \mathbf{g :} 83.8 \mu \mathrm{m} ; \mathbf{h :} 173.2 \mu \mathrm{m}$. 

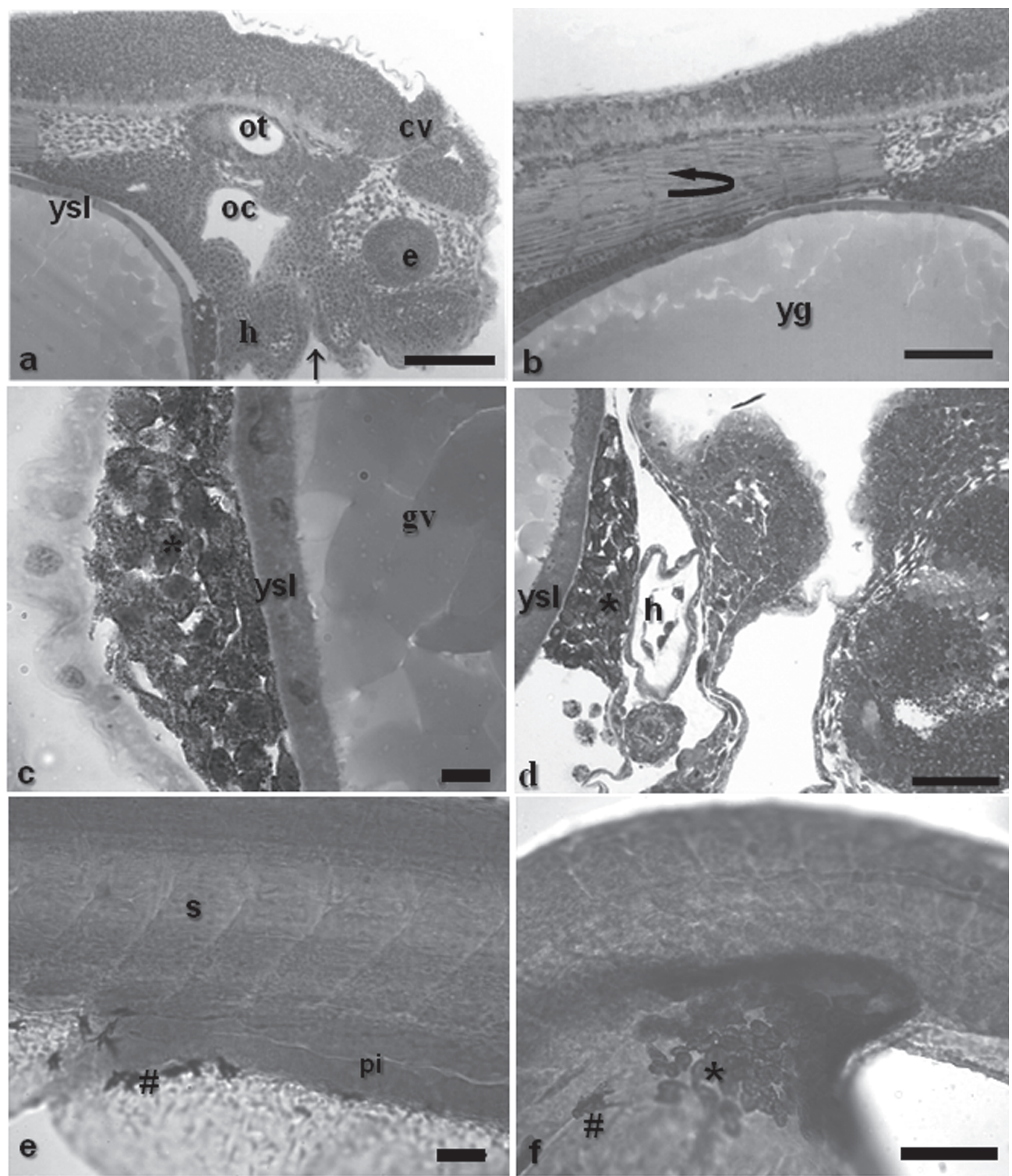

Fig. 9. a - head detail, showing the otic vesicle, oral cavity, cephalic vesicle, closed mouth and eye. b - myogenesis process; $\mathbf{c}$ and $\mathbf{d}$ - detail of punctiformes chromatophores caudal and cephalic extremities of the yolk sac, respectively, and heart; $\mathbf{e}$ development of posterior intestine; f - dendritic chromatophores at the end of the yolk sac. Staining: HE. ot: otic vescile; oc: oral cavity; cv: cephalic vesicle; arrow : closed mouth; ysl: yolk syncyctial layer; e: eye; h: heart; yg: yolk globules in the embryo; curved arrow: myogenesis process; number sign: dendritic chromatophores; asterisks: punctiformes chromatophores; pi.: posterior intestine. Scale bars: a: $139.3 \mu \mathrm{m} ; \mathbf{b :} 139.3 \mu \mathrm{m} ; \mathbf{c}: 10 \mu \mathrm{m} ; \mathbf{d}: 10 \mu \mathrm{m} ; \mathbf{e}: 141,9 \mu \mathrm{m} ; \mathbf{f : 3 5 , 6} \mu \mathrm{m}$. 
despite the utilization of young breeders and a constant water temperature, incubation at $25^{\circ} \mathrm{C}$ led to a higher asynchrony of embryonic development and a variation in blastomere division. Some authors such as Arezon et al. (2002) and Ninhaus-Silveira et al. (2006) have also shown that, coupled with a natural variation, the water temperature during incubation also interferes with the homogeneity of embryo development.

According to the results by Long \& Ballard (1976) in Catostomus commersoni and Matkovic et al. (1985) in Rhamdia sapo, the formation of the yolk syncyctial layer (YSL) begins during morula phase, as reinforced by the data from the present experiment. However, Cardoso et al. (1995), analyzing the embryogenesis of Pseudoplatystoma coruscans and González-Doncel et al. (2005) in Oryzias latipes reported that this layer begins to be formed during the blastula stage.

This layer can be regarded as an extra-embryonic organ being found only in teleosteans, and thus not contributing for the embryo formation, but playing a role in the yolk breakage, turning it viable for the embryo cells (Kimmel et al., 1995). In Pimelodus maculatus, yolk globules could be observed in the yolk syncyctial layer close to the blastoderm, differently from the report by Ninhaus-Silveira et al. (2007) in Prochilodus lineatus. The YSL membrane projections that extended between the yolk globules, as well as the presence of small yolk portions in YSL, indicate that the vitellinic material is partitioned and then transferred into the blastoderm. It can be inferred that the nutritive content passes through the plasmatic membrane under the form of small molecules and then it is reconstituted in the cytoplasm of blastoderm cells.

The blastula stage is characterized by the formation of blastocoele (formation of a large space between the yolk and the blastomeres). In this species the formation of a blastocoele has also been observed, represented by irregular spaces among some blastoderm cells, as described by several authors for other teleostean species (Marques 2008, Trinkaus, 1984; Ganeco, 2003). Regarding the irregular spaces that arise between blastoderm cells, Kimmel et al. (1995) have suggested that this stage could be better defined as the stereoblastula, since the formation of the blastocoel cavity has not yet formed. However, other authors have not differentiated between these stages in teleosteans and merely report the presence of the blastocoel (Lagler et al. 1977 apud Faustino et al., 2010).

The gastrula stage begins with the first epiboly movements (Leme dos Santos \& Azoubel, 1996) and is completed by closure of the blastopore by the blastoderm and the formation of a tail button (Kimmel et al., 1995). These observations are in accordance with what was detected in Pimelodus maculatus. The gastrula stage began after two hours and fifteen minutes of development at $29^{\circ} \mathrm{C}$ and after one hour and forty minutes at $25^{\circ} \mathrm{C}$. In Pimelodus maculatus, the formation of the embryonic shield becomes visible when the blastoderm encompasses 50\% of the yolk sphere, being in accordance with previous reports in other species (Kimmel et al., 1995; Ganeco, 2003; NinhausSilveira et al., 2006). On the other hand, in Oreochromis niloticus, Morrison et al. (2001) reported that, due to the size of yolk, the embryo is not able to extend over the entire vegetal pole and, thus, rudimentary organogenesis (somite segmentation) starts before the epiboly movement is finished. The blastopore closure was observed five hours after fertilization at $29^{\circ} \mathrm{C}$ and six hours after fertilization at $25^{\circ} \mathrm{C}$. Previous studies with the same species carried out by Luz et al. (2001) showed the beginning of gastrulation after two hours of embryonic development at $23.1 \pm 0.5{ }^{\circ} \mathrm{C}$ and the blastopore closure occurred five hours and fifty minutes after fertilization.

Following the gastrulation, comes the organogenesis stage. The formation of somites is necessary in the organization of the segmental pattern of vertebrate embryos. These structures are transitory muscular precursors that develop into cell blocks (Gilbert, 2003). The beginning of the somitogenesis in Pimelodus maculatus took place after blastopore closure and the end of epiboly, as also reported for Rhamdia quelen (Amorim et al., 2009); Leporinus piau (Borçato et al., 2004); Prochilodus lineatus (Ninhaus-Silveira et al., 2006) and three trahira species (Gomes et al., 2007). In Pimelodus maculatus, the embryo was differentiated after seven hours at $29^{\circ} \mathrm{C}$ and nine hours at $25^{\circ} \mathrm{C}$. In the same species, Luz et al. (2001) observed that the embryo differentiation occurred after 10 hours and 50 minutes of incubation at $23.1 \pm 0.5^{\circ} \mathrm{C}$.

As mentioned previously, the morphological changes during embryogenesis, being beside species-specific, are closely related to temperature variation. However Kimmel et al. (1995) point out that comparisons of embryos raised at different temperatures should be made with caution, because there is not assurance that all features of the embryo change coordinately their rates of development when the temperature is changed. The difference in hatching time might be due to environmental conditions water flow, alkalinity, $\mathrm{pH}$ (Cussac et al., 1985), may be related to biotic factors such as age, size of the breeding or nutritional factors. In addition, other environmental factors not detected in the water could have affected developmental period of the embryos.

No information was available to help us identify the structure located within the YSL and further studies are required to elucidate its function, if any.

The anterior region of the neural tube in the studied species expanded to form the prosencephalon, mesencephalon and rhombencephalon regions, similar to the patterns described in Pseudoplatystoma coruscans (Marques et al., 2008) and Prochilodus lineatus (Ninhaus-Silveira et al., 2006).

Brummett \& Dumont (1978) and Morrison et al. (2001) found the Kupffer's vesicle stage in the early stages of organogenesis, as in our study this vesicle is observed in early neurula and at the end of this phase disappears. According Hisaoka \& Firlit (1960) Kupffer's vesicle represents a reminiscent structure of arquenteron and is located above of the periblasto and below of the notochord. In Oncorhynchus keta (Mahon \& Hoar, 1956 apud Hisaoka \& Firlit, 1960) Kupffer's vesicle cavity is described as an oblique and elongated, with walls of columnar epithelium, which is separated from periblasto by a layer of endodermic cells, similar 
to that described by Ninhaus-Silveira et al. (2006) in Prochilodus lineatus. Brummet \& Dumont (1978) raised a hypothesis that this could have a digestive function, favorable to yolk resorption by the embryo, since several ciliated cells were observed inside Kupffer's vesicle and the intestines of Fundulus heteroclitus. Pimelodus maculatus Kupffer'svesicles showed a histological constitution as described above, but was not detected ciliated cells.

Studies about chromatophores and body or eye pigmentation are helpful as taxonomic traits for species identification (Meijide \& Guerreiro 2000). Nakatani et al. (2001) described two types of chromatophores: punctiforme, when present as small spots, and dendritic, when they assume an irregular shape with projections into distinct directions. In this work, the pigmentations has intensified and irregularly distributed, the chromatophores started migrating throughout the body by using pseudopodia for moving and then changed from punctiforme into a dendritic shape. Some fish species present only dendritic chromatophores, such as Rhinelepis aspera (Perini et al., 2010), others have just dot-like chromatophores, like Rhamdia quelen (Amorim et al., 2009) and Hoplias lacerdae and Hoplerythrinus unitaeniatus (Gomes et. al., 2007), whereas Hoplias malabaricus (Gomes et al., 2007) presents both types, just like observed in the present work.

Right after hatching, the larvae of Pimelodus maculatus were pigmented, differently from what has been observed by Faustino et al. (2007) in surubins hybrids and by Marques et al. (2008) in Pseudoplatystoma coruscans. In the present experiment, the larvae present a mean total length higher than that reported by Luz et al. (2001) at temperature $23,1 \pm 0,5^{\circ} \mathrm{C}$ and Sato (1999) at temperature between 24 and $25^{\circ} \mathrm{C}$.

The present data, therefore, showed that the study of embryonic development is essential to a better knowledge of some biological features of a species, helpful to elucidate issues related to fish rearing at this stage, being also useful to further taxonomic, ecological and conservational studies in the Pimelodus maculatus.

\section{Acknowledgements}

The authors are grateful to the Centro de Pesquisa e Gestão de Recursos Pesqueiros Continentais - ICMBIO/ Pirassununga/ São Paulo/ Brazil, which provided the fish specimens and the facilities, and to FAPESP (Fundação de Amparo a Pesquisa do Estado de São Paulo) for the financial support.

\section{Literature Cited}

Amorim, M. P., B.V. C. Gomes, Y. S. Martins, Y. Sato, E. Rizzo \& N. Bazzoli. 2009. Early development of the silver catfish Rhamdia quelen (Quoy \& Gaimard, 1824) (Pisces: Heptapteridae) from the São Francisco River Basin, Brazil. Aquaculture Research, 40: 172-80.
Andrade-Talmelli, E. F., E. T. Kavamoto, E. Romagosa \& N. FenerichVerani. 2001. Embryonic and larvae development of the Piabanha, Brycon insignis, Steindachner, 1876 (Pisces, Characidae). Boletim do Instituto de Pesca, 27: 21-28.

Arezon, A., C. A. Lemos \& M. B. C. Boher. 2002. The influence of temperature on the embryonic development of the annual fish, Cynolebias melanotaenia (Cyprinodontiformes; Rivulidae). Brazilian Journal of Biology, 62: 743-747.

Balinsky, B. I. 1970. An Introduction to Embryology. Philadelphia, W. B. Saunders, 353 pp.

Borçato, F. L., N. Bazzoli \& Y. Sato. 2004. Embriogenesis and larvae ontogeny of the "piau-gordura", Leporinus piau (Fowler) (Pisces, Anostomidae) after induced spawning. Revista Brasileira de Zoologia, 21: 117-122.

Brummett, A. R. \& J. N. Dumont. 1978. Kupffer's vesicle in Fundulus heteroclitus: a scanning and transmission electron microscope study. Tissue Cell, 10: 11-22.

Cardoso, E. L., M. S. D. Alves, R. M. A. Ferreira \& H. P. Godinho 1995. Embryogenesis of the neotropical freshwater siluriforme Pseudoplatystoma coruscans. Aquatic Living Resources, 8: 343-346.

Castagnolli, N. 1979. Fundamentos da nutrição de peixes. Piracicaba, Livroceres Ltda, 107p.

Castagnolli, N. 1992. Criação de peixes de água doce. Jaboticabal, FUNEP, 189 p.

Castellani, L. R., H. G. Tse, H. S. Leme dos Santos, R. H. S. Faria \& M. L. S. Santos. 1994. Desenvolvimento embrionário do curimbatá Prochilodus lineatus (Valenciennes, 1836) (Cypriniformes, Prochidontidae). Revista Brasileira de Ciências Morfologicas, 11: 99-105.

Cussac, V. E., M. V. Matkovic \& M.C. Maggese. 1985. Desarrollo embrionário de Rhamdia sapo (Valenciennes, 1840) Eigenmann y Eigenmann, 1888 (Pisces, Pimelodidae), I. Organogenesismedia organogenesis tardia y eclosion. Revista Brasileira de Biologia. 45: 149-60.

Faustino, F., L. S. O. Nakaghi, C. Marques, L. C. Makino \& J. A. Senhorini. 2007. Fertilização e desenvolvimento embrionário: morfometria e análise estereomicroscópica dos ovos dos híbridos de surubins (pintado, Pseudoplatystoma corruscans x cachara, Pseudoplatystoma fasciatum). Acta Scientiarum Biological Sciences, 29: 49-55.

Faustino, F., L. S. O. Nakaghi, C. Marques, L. N. Ganeco, L. C. Makino. 2010. Structural and ultrastructural characterization of the embryonic development of Pseudoplatystoma spp. Hybrids. International Journal of Developmental Biology, 54:723-730.

Ganeco, L. N. 2003. Análise dos ovos de piracanjuba, Brycon orbignyanus (Valenciennes, 1849), durante a fertilização e o desenvolvimento embrionário, sob condições de reprodução induzida. Dissertação, Centro de Aquicultura, Universidade Estadual Paulista, Jaboticabal. 65p.

Gilbert, S.F. 2003. Biologia do Desenvolvimento. Quinta edição. Ribeirão Preto, FUNPEC, 962 p.

Godinho, H. M., N. A. Fenerich \& M. Y. Narahara. 1978. Desenvolvimento embrionário e larval de Rhamdia hilarii (Valenciennes, 1840) (Siluriformes, Pimelodidae). Revista Brasileira de Biologia, 38:151-156.

Godoy, M. P. D. E. 1987. Peixes do Estado de Santa Catarina. Florianópolis, Universidade Federal de Santa Catarina, 572p.

Gomes, B. V. C., R. S. Scarpelli, F. P. Arantes, Y. Sato, N. Bazzoli \& E. Rizzo. 2007. Comparative oocyte morphology and early development in three species of trahiras from the São Francisco River Basin, Brazil. Journal of Fish Biology, 70: 1412-1429. 
Gonzalez-Doncel, M., M. S. Okihiro, S. A. Villalobos, D. E. Hinton \& J. V. Tarazona. 2005. A quick reference guide to the normal development of Oryzias latipes (Teleostei, Adrianichthyidae). Journal of Applied Ichthyology, 21: 39-52.

Hisaoka, K. K. \& C. F. Firlit.1960. Further studies on the embryonic development of the zebrafish, Brachidanio rerio (Hamilton-Buchanan). Journal of Morphology, 107: 205-225.

Kimmel, C. B., W. W. Ballard, S. R. Kimmel, B. Ullmann \& T. F. Schilling. 1995. Stages of Embryonic Development of the zebrafish. Developmental Dynamics, 203: 253-310.

Lagler, K. F. 1959. Freshwater Fishery Biology. 2nd edn. Dubuque: WM.C. Brown Company, 421 p.

Landines, M. A., J. A. Senhorini, A. I. Sanabria \& E. C. Urbinati. 2003. Desenvolvimento embrionário do pintado (Pseudoplatystoma coruscnas Agassiz, 1829). Boletim Técnico do CEPTA, 16: 1-13.

Leme dos Santos, H. S. \& R. Azoubel.1996. Embriologia Comparada. Jaboticabal, FUNEP, 189p.

Long, W. L. \& W.W. Ballard. 1976. Normal embryonic stages of the white suckers, Catostomus commersoni. Copeia, 1976: 342-351.

Luz, R. K., D. A. Reynalte-Tataje, A. A. Ferreira \& E. ZaniboniFilho. 2001. Desenvolvimento Embrionário e Estágios Larvais do Mandi-Amarelo Pimelodus maculatus. Boletim do Instituto de Pesca, 27 (1): 49-55.

Marques C., L. S. O. Nakaghi, F. Faustino, L. N. Ganeco \& J. A. Senhorini. 2008. Observation of the embryonic development in Pseudoplatystoma coruscans (Siluriformes: Pimelodidae) under light and scanning electron microscopy. Zygote, 16 (November): 333-342.

Marques, C. 2008. Análise histológica e de microscopia eletrônica do desenvolvimento inicial de jaú (Zungaro jahu). Dissertação, Centro de Aquicultura da Unesp, Universidade Estadual Paulista, Jaboticabal. 89p.

Matkovic, M. V., V. E. Cussac, M. Cukier, G. A. Guerrero \& M. C. Maggese. 1985. Dessarrollo embrionário de Rhamdia sapo (Valenciennes, 1840) Eingenmann y Eingenmann, 1888 (Pisces, Pimelodidae). I. Segmentación, morfogénesis y organogenesis temprana. Revista Brasileira de Biologia, 45: 39-50.

Meijide, F. J. \& G. A. Guerrero. 2000. Embryonic and larval development of a substrate-brooding cichlid Cichlasoma dimerus (Heckel, 1840) under laboratory conditions. Journal of Zoology London, 252: 481-493.

Morrison C. M., T. Miyake \& J. R.Wright Jr. 2001. Histological study of the development of the embryo and early larva of Oreochromis niloticus (Pisces; Cichlidae). Journal of Morphology, 247:172-195.

Nakagui, L. S. O., C. Marques, F. Faustino, L. N. Ganeco \& J. A. Senhorini. 2006. Desenvolvimento embrionário do dourado (Salminus brasiliensis) por meio de microscopia eletrônica de varredura. Boletim Técnico do Cepta, 19: 9-19.

Nakatani, K., A. A. Agostinho, G. Baumgartner, A. Bialetzki, P. V. Sanches, M. C. Makrakis \& C. S. Pavanelli. 2001. Ovos e larvas de peixes de água doce - Desenvolvimento e manual de identificação. Maringá, Editora da Universidade Estadual de Maringá, 378p.

Ninhaus-Silveira, A., F. Foresti \& A. Azevedo. 2006. Structural and ultrastructural analysis of embryonic development of Prochilodus lineatus (Valenciennes, 1836) (Characiforme, Prochilodontidae). Zygote, 14: 217-229.
Ninhaus-Silveira, A., F. Foresti, A. Azevedo, C. A. Agostinho \& R. Verissimo-Silveira. 2007. Structural and ultrastructural characteristics of the yolk syncytial layer in Prochilodus lineatus (Valenciennes, 1836) (Teleostei;Prochilodontidae). Zygote, 15: 267-271.

Nomura, H. 1978. Aquicultura e Biologia de Peixes. Nobel, São Paulo, 200p.

Pereira, C. R., L. J. G. Barcellos, L. C. Kreutz, R. M. Quevedo, F. Ritter \& L. B. Silva. 2006. Embryonic and larval development of Jundiá (Rhamdia quelen, Quoy \& Gaimard, 1824, Pisces, Teleostei), a South American Catfish. Brazilian Journal of Biology, 66: 1057-1063.

Perini, V. R., Y. Sato, E. Rizzo \& N. Bazzoli. 2010. Biology of eggs, embryos and larvae of Rhinelepis aspera (Spix \& Agassiz, 1829) (Pisces: Siluriformes). Zygote, 18: 159-171.

Reis, R. E., S. O. Kullander \& C. J. Ferraris Jr. 2003. Check list of the freshwater fishes of south and Central America. Porto Alegre, Edipucrs, 729p.

Ribeiro, C. R., H. S. Leme dos Santos \& A. A. Bolzan. 1995. Estudo comparativo da embriogênese de peixes ósseos (Pacu, Piaractus mesopotamicus; Tambaqui, Colossoma macropomum e híbrido Tambacu). Revista Brasileira de Biologia, 55: 65-78.

Riehl, R. \& R. A. Patzner. 1998. Minireview: the modes of egg attachment in teleost fishes. Italian Journal of Zoology, 65: 415-420.

Rizzo, E. Y. Sato, B. P. Barreto \& H. P. Godinho. 2002. Adhesiveness and surface patterns of eggs in neotropical freshawater teleosts. Journal Fish Biology, 61: 615-632.

Sato, Y. 1999. Reprodução de peixes da bacia do rio São Francisco: indução e caracterização de padrões. Tese (Doutorado em Ecologia e Recursos Naturais), Centro de Ciências Biológicas e da Saúde, Universidade Federal São Carlos, São Carlos. 198 p.

Sato, Y., N. Fenerich-Verani, A. P. O. Nuñer, H. P. Godinho, J. R. Verani. 2003. Padrões reprodutivos de peixes da bacia do São Francisco. In Águas, peixes e pescadores do São Francisco das Minas Gerais (eds. H. P. Godinho \& A. L. Godinho), Editora PUC Minas. Belo Horizonte:CNPq/PADCT, 229-279p.

Shardo, J. D. 1995. Comparative Embriology of Teleosten Fishes. I. Development and Staging of the American Shad, Alosa sapidissima (Wilson, 1811). Journal of Morphology, 225: 125-167.

Trinkaus, J. P. 1984. Mechanism of Fundulus epiboly - a current review. American Zoologist, 24: 673-688.

Vazzoler, A. E. A. M. 1996. Biologia da reprodução de peixes teleósteos: teoria e prática. Maringá: EDUEM, São Paulo: SBI, 169p.

Weingartner, M. \& E. Zaniboni Filho. 2004. Efeito de fatores abióticos na larvicultura de pintado amarelo Pimelodus maculatus (Lacépède, 1803): salinidade e cor do tanque. Acta Scientiarum Animal Sciences, 26 (2): 151-157.

Woynarovich, E. \& L. Horváth. 1983. A propagação artificial de peixes de água tropicais: manual de extensão. Brasília: FAO/ CODEVASF/CNPq, 225p.

Submitted June 2, 2010

Resubmitted April 7, 2011

Accepted July 5, 2011

Published September 16, 2011 